\title{
The Relative Contribution of The Male and Female to The Variation in Reproductive Success in Eucalyptus globulus
}

\author{
By S. Suitor ${ }^{1)}$, B. M. Potts ${ }^{2)}$, M. H. McGowen ${ }^{2)}$, D. J. Pilbeam ${ }^{3)}$, P. H. Brown, A. J. Gracie and P. L. Gore ${ }^{4)}$ \\ Tasmanian Institute of Agricultural Research, School of Agricultural Science, University of Tasmania, \\ Private Bag 54, Hobart, Tasmania, Australia 7001
}

(Received $8^{\text {th }}$ June 2008)

\begin{abstract}
Low and variable capsule and seed set is a major factor limiting seed production in Eucalyptus globulus seed orchards. This study identified the relative contribution of the maternal and paternal parent to reproductive success in E. globulus, and examined the genetic basis to the observed variation. Reproductive success was measured in terms of the number of viable seeds obtained per flower crossed. Data on the reproductive success of numerous genotypes from the Furneaux, Strzelecki Ranges and Otways races were obtained from: (i) 12 years of operational full-sib crossing; (ii) a designed fullsib diallel mating scheme; and (iii) capsule retention trials conducted over three seasons at two Tasmanian seed orchards on the same ramets of different genotypes. Analysis of the sparse operational data revealed that both male and female factors significantly affected reproductive success, accounting for $5.0 \%$ and $7.9 \%$ of the variation respectively. The more precise diallel crossing revealed that a large, and significant, proportion $55 \%$, of the variation in reproductive success between crosses at a single site was explained by the female parent. The male parent explained only $6.7 \%$, but this effect was not statistically significant and was related to variation in in vitro pollen germination. The significant female effect was found to be consistent at the genotype level across seasons, sites and pollination techniques suggesting a genetic basis to the variation. It is argued that selection of genetically fecund females is a key consideration in reducing costs of manual pollination for breeding and deployment purposes.
\end{abstract}

Key words: Eucalyptus globulus, capsule set, seed set, capsule abortion, reproductive success, mating system, parental contribution.

\section{Introduction}

Eucalyptus globulus Labill. (Tasmanian Blue Gum) is endemic to south-eastern Australia but is widely grown in plantations in temperate regions of the world for pulpwood production (COTTERILL et al., 1999; ELDRIDGE et al., 1993; PотTs, 2004). It is one of four taxa in the E. globulus complex (BROOKER, 2000) that are differenti-

\footnotetext{
1) Corresponding author: SHAUN SUITOR. Ph: +61 362262621 , Fax: +61-3-6226 2642. E-Mail: ssuitor@utas.edu.au.

2) School of Plant Science and Cooperative Research Centre for Forestry, University of Tasmania, Private Bag 55, Hobart, Tasmania, Australia 7001.

3) Southern Tree Breeding Association Inc., 2 Eleanor St, Mount Gambier, South Australia, Australia 5290.

4) SeedEnergy, Pty Ltd, Private Bag 55 Hobart, Tasmania, Aus-
} tralia 7001. ated on reproductive traits, including the size and number of flower buds per umbel (JoRDAN et al., 1993). Eucalyptus globulus is genetically variable across its geographic range and the broad-scale, quantitative genetic variation in numerous traits has been summarised by classifying the native gene pool into a hierarchy of 13 races (DUTKOwski and PoTTs, 1999).

Eucalyptus globulus has a mixed mating system (PотTs et al., 2008) with trees being able to set seed after self- or outcross-pollination (HARDNER et al., 1996). Self pollinated offspring are subject to severe inbreeding depression, with a $48 \%$ reduction in the volume growth of trees from selfed progeny compared with fully outcrossed progeny reported (HARDNER and POTTS, 1995). Outcrossing rates in native stands range from 38 to $100 \%$ (Foster et al., 2007; HARDNER et al., 1996; MCGowen et al., 2004b; PATTERSON et al., 2001) and, therefore, seed may be subject to inbreeding depression and, thus, suboptimal for deployment (HodGe et al., 1996; VOLKER, 2002). Self incompatibility is believed to be a major factor determining the level of outcrossing (PATTERSON et al., 2004b) and has been shown to be variable in E. globulus and under genetic control (MCGowen, 2007). Currently most improved E. globulus plantations are established from seedlings derived from seedling (GRIFFIN, 2001; MCGowen et al., 2004a; TIBBITS et al., 1997) or grafted (PATTERSON et al., 2004b) openpollinated (OP) seed orchards, or through large-scale manual pollination systems (HARBARD et al., 1999; PATTERSON et al., 2004a; WILLIAMs et al., 1999). Manual pollination systems have been developed in this species to minimise the effects of inbreeding depression and contamination from unimproved pollen sources (JONES et al., 2006) as well as allow both additive and non-additive genetic effects to be exploited by controlling the female and male parent and deploying elite full-sib families (DutKowski, 2004; Pоттs et al., 2007).

The traditional controlled-pollination (CP) technique used in eucalypts involved three visits (TVP) emasculation and isolation at operculum shed, pollination at stigma receptivity and then removal of isolation bags several weeks later (ELDRIDGE et al., 1993). However, refinements have brought about the single-visit (SVP) (WILliAMS et al., 1999) or one-stop (OSP) (HARBARD et $a l ., 1999)$ pollination techniques whereby cutting of the non-receptive style, coupled with style or flower isolation, has allowed pollination with no contamination from undesirable pollen to be undertaken in one visit. Further refinements have brought about the MSP tech- 
nique, which involves no emasculation or isolation, merely cutting $1 \mathrm{~mm}$ off the tip of the style and applying pollen to the cut surface (PATTERSON et al., 2004a). MSP is now routinely used for the mass production of full-sib E. globulus seed for the forestry industry in Australia (CAllister and Collins, 2007; PotTs et al., 2007). Although the level of contamination with MSP is estimated to be about $13 \%$, most of this is expected to be from outcross pollen of high genetic quality (PATTERSON et al., 2004a) and the level of self pollination in OSP/SVP has been reported to be low (PATTERSON et al., 2004a).

A major problem identified in manual pollination is that a significant proportion of flowers do not set fruit (Suitor et al., 2008b). This is often confounded with low numbers of seed per capsule, and together these factors may result in poor seed set per flower pollinated (a measure of reproductive success), which substantially increases the cost of commercial seed production (CALLISTER and Collins, 2007; McGowen, 2007). The seed output of a tree may be affected by environmental and genetic factors (McGowen et al., 2004a). Variation in whole tree seed output has been reported in several studies of eucalypts growing in native stands (DRAKE, 1981; PotTs, 1986; PotTs and REID, 1983) and in a seed orchard system (McGowen, 2007; SAsse et al., 2003b). LEAL and COTTERILL (1997) noted that seed production varies markedly between $E$. globulus trees, and the choice of female could strongly influence the profitability of seed production. MCGowen (2007) found a genetic basis to the variation in number of seeds per capsule for E. globulus. However, all studies to date suggesting both a difference in whole tree seed output and a genetic basis to the variation in reproductive output, have been based on OP systems. As OP confounds the effects of selfing, differences in reproductive output may not be correlated between $\mathrm{OP}$ and hand pollination (CP and MSP) systems.

The present study aims to identify the relative contribution and stability of the female and male parent to reproductive success (as measured by seed per flower crossed) in E. globulus. We compare these effects (i) across 12 years of operational CP crossing across multiple sites and (ii) in a designed full-sib diallel mating scheme undertaken at a single site. We then use specific crossing experiments (designed to analyse capsule retention rates) undertaken on ramets of different genotypes, over different seasons, sites and pollination types to test the stability of reproductive success in the face of different conditions and to provide an insight into the genetic basis of variation in female reproductive success. We examine overall reproductive success as well as the specific components of capsule set and seed per capsule.

\section{Materials and Methods}

\section{Seed orchards and trees}

The majority of trees used in this study were grafted selections that were grown in $E$. globulus arboreta (Table 1). The arboreta were located across Australia, they ranged in altitude from $40 \mathrm{~m}$ to $340 \mathrm{~m}$, the annual rainfalls ranged from $500 \mathrm{~mm}$ to $1200 \mathrm{~mm}$, the average maximum temperatures ranged from $17.4^{\circ} \mathrm{C}$ to $22.2^{\circ} \mathrm{C}$ and the average minimum from $7.6^{\circ} \mathrm{C}$ to $9.6^{\circ} \mathrm{C}$. All trees in the arboreta were selected from the base population of the Australian National E. globulus Breeding Program run by the Southern Tree Breeding Association (STBA) (Pilbeam and DutKowski, 2004). Trees chosen for study had abundant flowers, and were first generation selections from the Furneaux Group, Otways and Strzelecki Range as defined by DUTKOwsKI and POTTS (1999). In most cases the ramets were unrelated except in the operational crossing, where crossing guidelines allow for up to three selections from the better-ranked base population families. Crossing in all cases was done between unrelated individuals.

\section{Experiments}

This study involved the analysis of three datasets, which were derived from a (i) collection of STBA operational crossing data (ii), a diallel crossing scheme, and (iii) various capsule retention trials specifically studying stability in female reproductive success (SUITOR et al., 2007). Trials were designed as detailed below.

\section{Operational crossing data}

Operational capsule set, seed per capsules and seed per flower data were obtained from the Southern Tree Breeding Association (STBA). This included capsule and seed set values for crosses made over 12 seasons from

Table 1. - Breeding arboreta locations and details.

\begin{tabular}{|c|c|c|c|c|c|c|c|}
\hline Site & Latitude & Longitude & $\begin{array}{c}\text { Elevation } \\
\text { (m) }\end{array}$ & $\begin{array}{c}\text { Rainfall } \\
\text { (mm) }\end{array}$ & $\begin{array}{c}\text { Average } \\
\text { maximum } \\
\text { temperature }\left({ }^{\circ} \mathrm{C}\right)\end{array}$ & $\begin{array}{c}\text { Average } \\
\text { minimum } \\
\text { temperature }\left({ }^{\circ} \mathrm{C}\right)\end{array}$ & Trials included \\
\hline Cambridge & $42^{\circ} 48^{\prime} \mathrm{S}$ & $147^{\circ} 25^{\prime} \mathrm{E}$ & 40 & 500 & 17,4 & 8 & Capsule retention trials, diallel crossing \\
\hline Ridgley & $41^{\circ} 08^{\prime}$ & $145^{\circ} 48^{\prime}$ & 275 & 1200 & 16,1 & 7,7 & Capsule retention trials, operational crossing \\
\hline $\mathrm{CS} 04$ & $34^{\circ} 15^{\prime}$ & $116^{\circ} 07^{\circ}$ & 276 & 1010 & 20,3 & 9,6 & Operational crossing \\
\hline $\mathrm{CS} 05$ & $34^{\circ} 15^{\prime}$ & $116^{\circ} 07^{\prime}$ & 276 & 1010 & 20,3 & 9,6 & Operational crossing \\
\hline $\mathrm{CS} 06$ & $34^{\circ} 14^{\prime}$ & $116^{\circ} 03^{\prime}$ & 290 & 940 & 22,5 & 8,4 & Operational crossing \\
\hline $\operatorname{Cs} 08$ & $34^{\circ} 14^{\prime}$ & $116^{\circ} 03^{\circ}$ & 290 & 940 & 22,5 & 8,4 & Operational crossing \\
\hline EG07 & $33^{\circ} 33^{\prime}$ & $116^{\circ} 04^{\prime}$ & 158 & 970 & 18,5 & 8,9 & Operational crossing \\
\hline EG09 & $34^{\circ} 33^{\prime}$ & $116^{\circ} 04^{\prime}$ & 235 & 1040 & 17,9 & 8,8 & Operational crossing \\
\hline EG16 & $34^{\circ} 33^{\prime}$ & $116^{\circ} 04^{\prime}$ & 235 & 1040 & 17,9 & 8,8 & Operational crossing \\
\hline Kingsclere & $41^{\circ} 10^{\prime}$ & $145^{\circ} 51^{\prime}$ & 339 & 1200 & 16 & 7,6 & Operational crossing \\
\hline Massy Greene & $41^{\circ} 50^{\prime}$ & $145^{\circ} 54^{\prime}$ & 132 & 1200 & 16,2 & 7,9 & Operational crossing \\
\hline Silver Creek & $38^{\circ} 19^{\prime}$ & $146^{\circ} 14^{\prime}$ & 200 & 1040 & 17,9 & 8,8 & Operational crossing \\
\hline
\end{tabular}


Table 2. - Summary table for the operational crossing data.

\begin{tabular}{lcccc}
\hline Female race & $\begin{array}{c}\text { Pollination } \\
\text { type }\end{array}$ & $\begin{array}{c}\text { Number of } \\
\text { females }\end{array}$ & $\begin{array}{c}\text { Average number of } \\
\text { males crossed per } \\
\text { female }\end{array}$ & $\begin{array}{c}\text { Number of } \\
\text { flowers } \\
\text { pollinated }\end{array}$ \\
\hline Furncaux & TVP & 30 & 4,3 & 1023 \\
Strzclecki Ranges & TVP & 29 & 4,6 & 1341 \\
Otways & TVP & 21 & 4 & 513 \\
Furneaux & SVP & 44 & 3,4 & 5757 \\
Strzelecki Ranges & SVP & 33 & 3,9 & 3978 \\
Otways & SVP & 37 & 4 & 4142 \\
\hline
\end{tabular}

1995-2006 at 11 arboreta across Australia (Table 1), as well as a small component from crosses undertaken on ortets growing in field trials (treated as a single 'site' category in analyses). With the exception of the selected ortets, all females were grafted selections. In total, the data represented crossing among 192 genotypes, 140 of which were represented as females and 152 as males, 100 were represented as males and females, 40 as just females and 52 as just males. The crossing was relatively sparse and the average number of males crossed per female varied between 3.4 and 4.6 (Table 2). Genotypes analysed were from three different races of $E$. globulus (Table 2), which included Strzelecki Ranges, Otways [Eastern and Western Otways races of DUTKOWsKI and Pоттs (1999) were combined due to their molecular similarity - see STEANE et al. (2006)] and Furneaux races. The data analysed were mainly from inter-race crosses, although some research crosses were included which involved intra-race crossing. Earlier pollinations were made with the three visit technique (TVP), (MONCUR, 1995; VENTER and SILVLAL, 2007), but with the development of the single visit pollination technique (SVP) in the late 1990's (HARBARD et al., 1999; WILLIAMS et al., 1999), most of the later crosses were undertaken with SVP.

The variation in $\log _{10}$ transformed seed per flower crossed for the operational data was analysed by fitting a mixed model where pollination technique was treated as fixed and the season, site, male, female and their two and three way interactions were treated as random effects. The fixed effect of female and male race and their interaction was included in a subsequent analysis where the random female and male and their interaction terms were nested within the relevant fixed effect (i.e. female race, male race and their interaction respectively). Analyses were undertaken using PROC MIXED of SAS version 9.1 (SAS Institute Inc, 2003) using the REML option to fit the model, the Wald $\mathrm{Z}$ test to estimate the significance of random effects, and an F-test based on the Type 3 sum of squares to test the significance of the fixed effects when included in the model.

\section{Diallel crosses}

A $30 \times 30$ diallel crossing scheme (same genotypes used as both males and females, to make all crosses possible combinations) involving ten females from each of three races of $E$. globulus (Strzelecki Ranges, Otways and Furneaux Group) was undertaken at the Cambridge orchard across seasons 2004/2005 and 2005/2006 as part of a University of Tasmania/STBA joint research project (Table 2). Some self-pollinations were undertaken but not included in this data set. In the 2004/2005 season, 27 female genotypes were crossed with up to 26 male genotypes using four flowers per pollen genotype per tree for a total of 459 combinations. In the following 2005/2006 season, 26 females were each pollinated with up to 29 males for a total of 443 combinations in an attempt to complete the full diallel, 162 combinations were repeated between seasons. In 2004/2005, pollen was collected and stored at $-20^{\circ} \mathrm{C}$ for approximately one month and used for $\mathrm{CP}$, with in vitro percentage germination averaging $12 \%$. In $2005 / 2006$, while some pollen collected in the same flowering season was used, most pollen was collected during the 2004/2005 crossing season and had been stored at $-20^{\circ} \mathrm{C}$ for 6 to 12 months. The percentage in vitro germination of all pollens used for CP crossing in 2005/2006 averaged $4.9 \%$. Three flowers were pollinated for each male-female combination. Flower physical measurements were also made at the time of pollination on each tree in the diallel.

Only those crosses undertaken in either 2004/2005 and 2005/2006 that used pollen collected in the same season were used in the analysis. Normality of the seed per flower crossed residuals was optimised in this data by the use of square root transformed data. The variation in reproductive success (square root of viable seed per flower crossed) data was analysed in several stages by fitting mixed models [PROC MIXED, SAS version 9.1; (SAS Institute Inc, 2003)], where a) male and female were treated as random effects and season a fixed effect, b) as (a) but fitting in vitro pollen germination percentage as a co-variate, c) as (a) but fitting capsule width as a covariate, and d) fitting male race, female race, their interaction and season as fixed effects and random female and male terms nested within their relevant race. PROC REG in SAS was used to regress reproductive success against pollen viability and PROC CORR was used to correlate viable seed per capsule, capsule set and viable seeds per flower.

\section{Specific tests of the stability of the female effect}

Some female genotypes were repeated across the operational crossing and the diallel crossing. To test the stability of the female effect the best linear unbiased predictions (BLUPs) of the random female effects (ignoring race of origin) obtained from analysis of the number of viable seed per flower crossed were correlated between the two data sets. 
Table 3. - Summary table for the females crossed with fresh pollen collected in the same season as crossing in the diallel at Cambridge in seasons 2004/2005 and 2005/2006. Capsule set, viable seed per capsule and flower were calculated on data summed across all crosses involving the female.

\begin{tabular}{|c|c|c|c|c|c|c|}
\hline \multirow[b]{2}{*}{ Genotype } & \multirow[b]{2}{*}{ Female race } & \multicolumn{3}{|c|}{ Number of } & \multirow[b]{2}{*}{$\begin{array}{l}\text { Viable seed } \\
\text { per capsule }\end{array}$} & \multirow[b]{2}{*}{$\begin{array}{l}\text { Viable seed } \\
\text { per flower }\end{array}$} \\
\hline & & $\begin{array}{c}\text { Number of } \\
\text { males }\end{array}$ & $\begin{array}{c}\text { flowers } \\
\text { pollinated }\end{array}$ & $\begin{array}{c}\text { Capsules } \\
\text { set }(\%)\end{array}$ & & \\
\hline 5642 & Furneaux & 13 & 47 & 55,3 & 22,1 & 12,2 \\
\hline 4489 & Furneaux & 9 & 36 & 61,1 & 40,3 & 24,6 \\
\hline 5927 & Furneaux & 13 & 55 & 54,5 & 65,7 & 35,8 \\
\hline 6891 & Furneaux & 13 & 51 & 66,7 & 47,4 & 31,6 \\
\hline 6029 & Furneaux & 13 & 51 & 96,1 & 43,1 & 41,4 \\
\hline 5856 & Furneaux & 14 & 55 & 81,8 & 53,1 & 43,4 \\
\hline 7066 & Furneaux & 12 & 48 & 87,5 & 64 & 56 \\
\hline 7910 & Furneaux & 14 & 54 & 90,7 & 81,2 & 73,7 \\
\hline 5617 & Furncaux & 14 & 55 & 96,4 & 105,9 & 102 \\
\hline 6071 & Furneaux & 14 & 55 & 85,5 & 137,8 & 117,7 \\
\hline 7537 & Otways & 28 & 109 & 20,2 & 28,2 & 5,7 \\
\hline 7335 & Otways & 21 & 78 & 64,1 & 11,3 & 7,3 \\
\hline 4928 & Otways & 27 & 101 & 62,4 & 17,1 & 10,7 \\
\hline 5032 & Otways & 13 & 52 & 73,1 & 19,6 & 14,3 \\
\hline 4886 & Olways & 26 & 99 & 76,8 & 24,6 & 18,9 \\
\hline 4862 & Otways & 14 & 54 & 85,2 & 27,7 & 23,6 \\
\hline 7479 & Otways & 2 & 6 & 100 & 18,3 & 18,3 \\
\hline 5508 & Strzelecki Ranges & 27 & 106 & 23,6 & 18,3 & 4,3 \\
\hline 5433 & Strzelecki Ranges & 27 & 103 & 46,6 & 19,7 & 9,2 \\
\hline 5449 & Strzelecki Ranges & 26 & 102 & 63,7 & 16 & 10,2 \\
\hline 5476 & Strzelecki Ranges & 12 & 45 & 62,2 & 24 & 14,9 \\
\hline 5411 & Strzelecki Ranges & 21 & 81 & 64,2 & 25,7 & 16,5 \\
\hline 5427 & Strzelecki Ranges & 14 & 52 & 75 & 23,1 & 17,3 \\
\hline 5474 & Strzelecki Ranges & 26 & 103 & 91,3 & 27,8 & 25,3 \\
\hline 5296 & Strzelecki Ranges & 15 & 58 & 70,7 & 40,8 & 28,8 \\
\hline 5592 & Strzelecki Ranges & 10 & 40 & 77,5 & 35,1 & 27,2 \\
\hline \multirow[t]{2}{*}{5407} & Strzelecki Ranges & 14 & 55 & 85,5 & 52,7 & 45,1 \\
\hline & Mean & 16,7 & 64,9 & 71 & 40,4 & 31 \\
\hline
\end{tabular}

In addition to the operational and diallel crossing, various trials were completed at two sites over three seasons, with three different pollination techniques as part of other studies (SUITOR et al., 2007) which involved common female genotypes and allowed the stability of female effects to be examined. The trials assessed the capsule set and seed per capsule values of different ramets of the same genotype, thus comparisons could be made assessing the consistency of genotype reproductive output in terms of viable seed per flower crossed. The data cross correlated was derived from several sources (termed trials A to D):

Trial A. CP, MSP and OP reproductive success assessed for seven genotypes in the 2004/2005 season at Cambridge, as a part of the diallel crossing trial and a trial studying the effects of pollination type on female success.

Trail B. OP reproductive success assessed on the same seven genotypes as Trial A but different ramets, as a part of a trial analysing the impact of flower density.

Trail C. CP and OP reproductive success assessed in $2005 / 2006$ on the same seven genotypes as Trial A but different ramets, as a part of a trial analysing the impact of flower density.
Trail D. MSP reproductive success assessed in 2005/2006 at the Ridgley site from six genotypes which were also assessed at Cambridge in the previous season (Trial A) as a part of a trial assessing the impact of site on female success.

The data on OP reproductive success obtained from the same genotypes but different ramets from Trails A and $\mathrm{B}$ were correlated to test whether the OP reproductive performance of different ramets of the same genotype at the same site in the same season is correlated. To test the stability of genotype cross-pollinated performance, the reproductive success of (i) different ramets of the same seven genotypes under CP was correlated across the 2004/2005 and 2005/2006 seasons (Trial A vs Trial C), and (ii) different ramets of the same six genotypes under MSP was correlated across different orchards and seasons (Trial A vs Trial D). As a robust test of whether OP performance can predict MSP performance, the reproductive success of the same six genotypes under OP (Trial A, Cambridge, 2004/2005) and MSP (Trial D, Ridgley, 2005/2006, MSP) were correlated across different seasons and sites.

Pearson's product moment correlation $(r)$, calculated with PROC CORR in SAS version 9.1 (SAS Institute 
Inc, 2003), was used for all correlations of reproductive success for different ramets of the same genotypes across the two sites and seasons and three pollination types. Spearman's rank correlation coefficient ( $\rho)$ was also used in conjunction with Pearson's for the correlation between the operational and the diallel crossing.

\section{Pollinations and data collection}

All pollen were collected, stored, germinated and scored as outlined by PotTs and MARSDEN-SMEDLEY (1989). For testing viability, pollen was streaked across the surface of an agar medium $(30 \%$ sucrose and $150 \mathrm{ppm}$ of boric acid) in $4 \times 4$ celled repli-dishes, and incubated at $25^{\circ} \mathrm{C}$ for 24 hours with a $12 \mathrm{hr} / 12 \mathrm{hr}$ photo period. Each pollen source was replicated in at least two cells of the repli-dish. Percentage germination was scored with a light microscope at 100x magnification.

All CP and MSP pollinations undertaken in the three Tasmanian seed orchards were conducted according SUITOR et al. (2008b). The STBA controlled pollinations were undertaken with both the SVP technique and the three-visit technique (TVP).

Approximately 12 months after pollination all $\mathrm{CP}$, MSP and OP (20 capsules per tree) capsules were mature (BOLAND et al., 1980; SASSE et al., 2003a), at which stage they were harvested, placed into individual paper envelopes and air dried. Once dried, the seeds were extracted and counted as viable (filled) following HARDNER and PoTTS (1995), to calculate seed set. For OP trees studied capsule set was estimated by placing two litter traps each measuring 1000 x 400 x 50 mm underneath each tree, one on the northern and the other on the southern side of the trunk. The number of opercula collected from the traps gave an indication of flower number, and the number of aborted capsules collected was divided by the number of opercula to give an estimate of the percentage capsule abortion. Reproductive success was then determined by multiplying seed set by capsule set.

\section{Results}

Operational crossing data

The STBA operational crossing data, which spans 12 years and 11 locations, showed a significant difference in the fixed effect of pollination technique ( $\log _{10}$ transformed; $F_{1,347}=9.23 ; P<0.01$ ). SVP resulted in a higher least-squared mean seed per flower (6.9) than TVP (4.8). When the random effects were tested, there was a significant male $(P=0.008)$ as well as female $(P=0.032)$ effect on seed per flower crossed (Table 4 ). The female explained $7.9 \%$ and the male $5.0 \%$ of the variation in reproductive success between crosses (Table 4). When the fixed female and male race terms, and their interaction, were fitted into the model the male race $\left(F_{2,149}=\right.$ $0.50 ; P=0.61$ ) was insignificant and the male by female

Table 4. - Sources of variation in reproductive success for the three races (Furneaux, Otways and Strzelecki Ranges) in the operational crossing program. The table shows the proportion (\%) of variation in reproductive success (log10 transformed seed per flower crossed) explained by year, location, male and female genotypes and their interactions treated as random effects.

\begin{tabular}{lcc}
\hline & $\begin{array}{c}\text { Percentage of } \\
\text { variation } \\
\text { explained }\end{array}$ & Probability \\
\hline Source of variation & 6,7 & 0,209 \\
Location & 5,8 & 0,228 \\
Female & 7,9 & $\mathbf{0 , 0 3 2}$ \\
Male & 5 & $\mathbf{0 , 0 0 8}$ \\
Season*location & 8,4 & 0,082 \\
Location*male & 2 & 0,161 \\
Location*female & 5,2 & 0,1 \\
Season*male & 2,8 & 0,173 \\
Scason*female & 6,5 & 0,098 \\
Season*location*female & 4,3 & 0,215 \\
Season*location*male & 1,4 & 0,332 \\
Location*female*male & $4, \mathbf{1}$ & 0,058 \\
Residual & 39,8 & \\
\hline
\end{tabular}

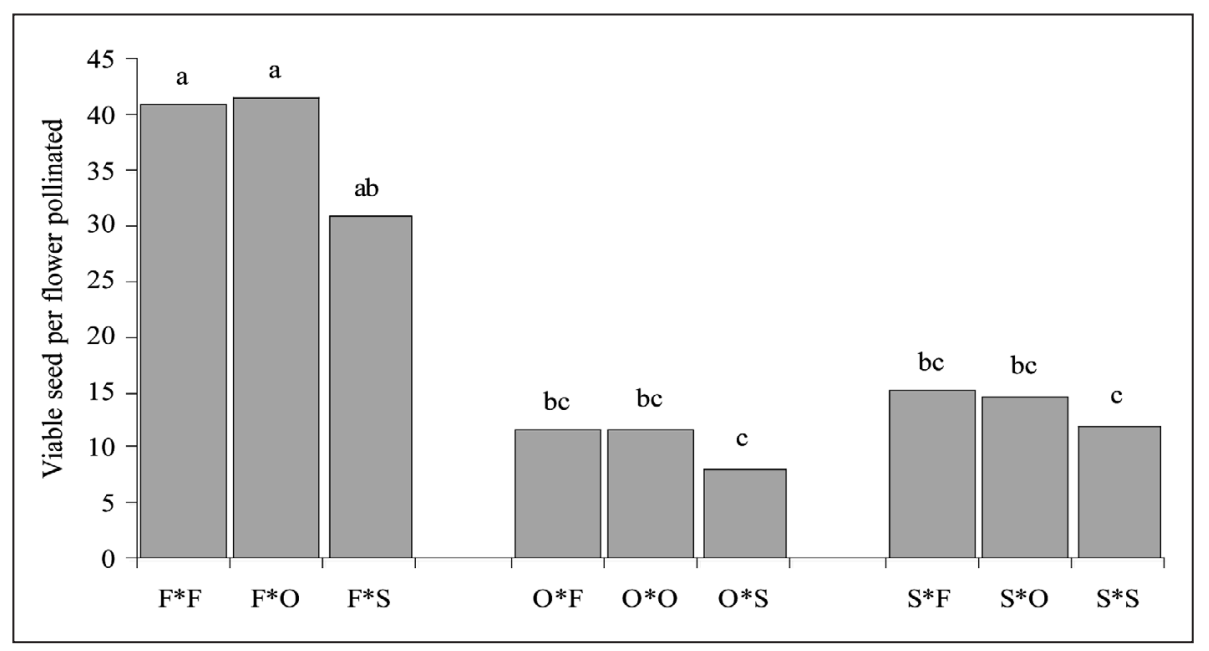

Figure 1. - Seed per flower obtained following single visit pollination (SVP) of each of the nine female by male race interactions within the diallel crossing scheme, Furneaux (F), Otways (O) and Strzelecki Ranges (S). Common letters within female interaction categories represent $\sqrt{ }$ back transformed least squared means which were not significantly $(P>0.05)$ different with Tukey Kremer multiple range test. 
race interaction $\left(F_{2,134}=2.10 ; P=0.059\right)$ effects and the female race $\left(F_{2,134}=2.94 ; P<0.056\right)$ effect were on the borderline of significance. When all sources of variation (Table 4) were combined including interaction terms, $28 \%$ of the variation in reproductive success was explained by those including the female as a source of variance and $15 \%$ was explained by those involving the male. By comparison, the main effect and interaction terms involving season and location accounted for $30 \%$ and $31 \%$ of the total variation respectively.

\section{Diallel crosses}

Analysis of the diallel crossing scheme data, which included only crosses that used fresh pollen collected in the same season, revealed that there was no difference in reproductive success between seasons $(\sqrt{ }$ transformed; $\left.F_{1,398}=2.00 ; P<0.200\right)$. The variation between females was shown to account for $55 \%$ of the variation in reproductive success between crosses $(Z=3.44 ; P<0.001)$ compared to only $6.7 \%$ for the male parent $(Z=2.62$; $P=0.005$ ). Both the number of viable seeds per capsule $(Z=3.46 ; P<0.001)$ and capsule set $(Z=3.19$; $P<0.001$ ) (which are positively inter-correlated; $\left.\mathrm{r}_{613}=0.26 ; P<0.001\right)$ significantly contributed to the variation in reproductive success between females.

When the fixed female and male race terms and their interaction were fitted into the model, the male race $\left(\sqrt{ }\right.$ transformed $\left.F_{2,24}=1.25 ; P=0.291\right)$ and male by female race interaction $\left(F_{2,24}=0.11 ; P=0.925\right)$ effects were insignificant and the female race effect was signifi- cant $\left(F_{2,24}=5.09 ; P=0.008\right)$. The significant female race effect was driven by the Furneaux race, which had a significantly higher reproductive success than both Otways and Strzelecki Ranges races (Figure 1). The Furneaux race had significantly $\left(F_{2,20}=16.52\right.$, $P<0.001$ ) larger capsules than the other two races and over all when fitted as a covariate it was found that variation between females in reproductive success was positively related $\left(F_{20,251}=2.6 ; P=0.005\right)$ to flower morphological features with capsule width being the only significant $\left(F_{20,83}=2.37 ; P=0.018\right)$ feature measured.

Pollen germination did not have a significant effect on reproductive success when crosses were done with pollen collected in the same season $(\sqrt{ }$ transformed $\left.F_{1,321}=0.64, P=0.425\right)$. When the full data set, including crosses which had been undertaken with fresh pollen and pollen that had been collected in the previous season was analysed, the small male effect experienced in the diallel crossing scheme is partly explained by in vitro pollen viability $\left(Y=0.6 \mathrm{X}+17.2 ; \mathrm{r}^{2}=0.2 ; P<0.01\right)$. Significantly higher reproductive success was observed between the pollinations made with pollen collected in the same season $(16 \pm 2.1$ seeds per flower, based on untransformed data) than that from pollinations made from stored pollen collected the previous season $(2.4 \pm 0.3)\left(\sqrt{ }\right.$ transformed; $\left.F_{1,227}=39.28 ; P<0.001\right)$. Average viability for the pollen that was collected and used in the same season was $12 \%$ and the average viability for the pollen collected in the previous season was $2.4 \%$.

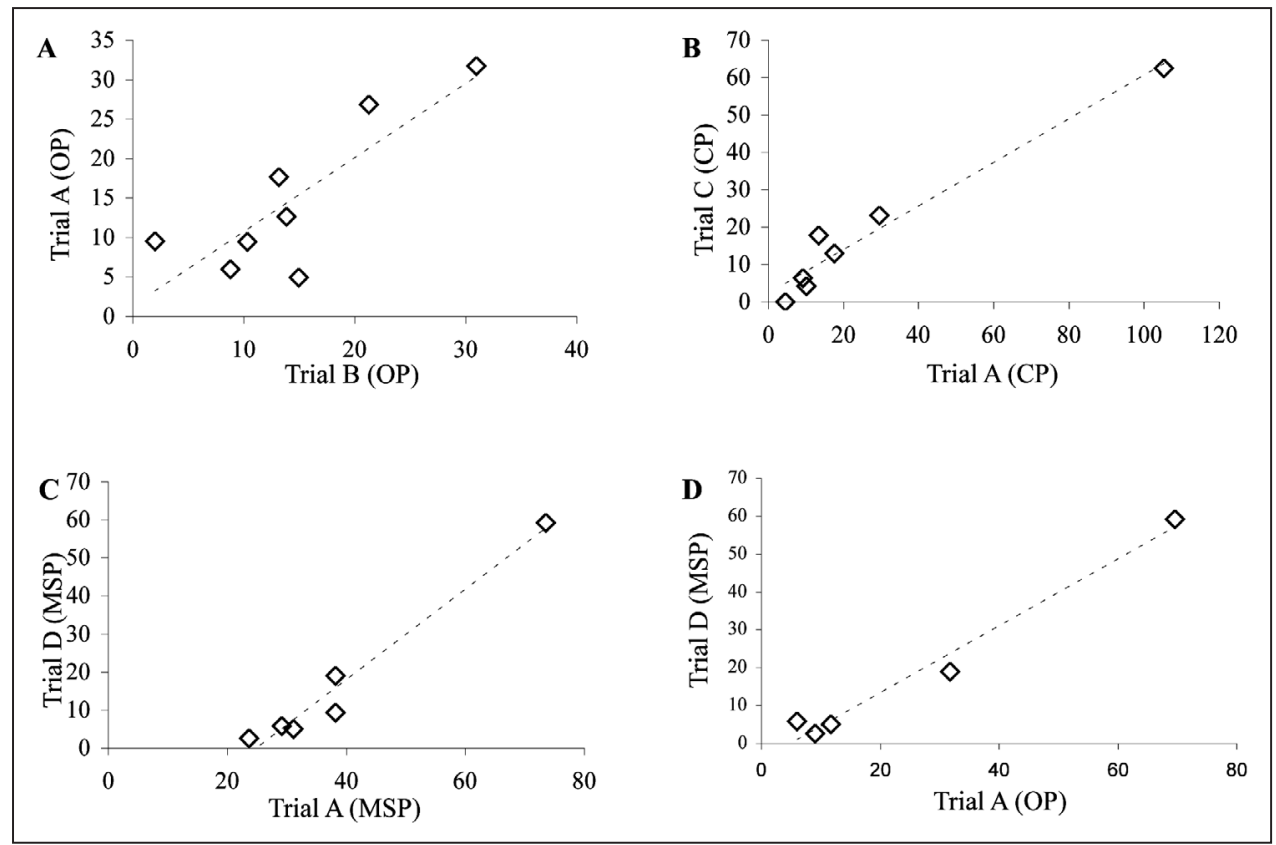

Figure 2. - Each of the points within the four graphs represent the mean seed obtained per flower pollinated for different ramets of the same genotype used for two different trials, for $(\mathbf{A})$ two open pollinated trials (trial A and B) at Cambridge 2004/2005, (B) two cross pollinated (SVP) trials (trial A and trial C) in Cambridge 2004/2005, (C) Two mass supplementary pollinated trials in Cambridge 2004/2005 (trial A) and in Ridgley 2005/2006 (trial D) and (D) an open pollinated trial in Cambridge 2005/2006 (trial A) and a mass supplementary pollinated trial in Ridgley 2005/2006. 


\section{Specific tests of the stability of female effect}

While the operational crossing data was clearly noisy and females poorly differentiated in reproductive success compared to the results obtained from the diallel crossing scheme, there was some level of repeatability in female success in these independent crossing schemes. The Pearson's correlation coefficient between the best linear unbiased predictions (BLUPs) of the random female effects (ignoring race of origin) obtained from analysis of the number of viable seed per flower crossed in the operational crossing and the diallel crossing was $\left(\mathrm{r}_{26}=0.40 ; P=0.043\right)$ and the Spearman rank correlation was even higher $\left(\rho_{26}=0.48 ; P=0.013\right)$.

In a separate series of experiments there were significant positive correlations in reproductive success of female genotypes when different ramets were pollinated with different pollination techniques, at different sites and within different seasons (Figure 2). This occurred (i) when different ramets of the same genotype were pollinated (OP) at the same site (Cambridge) and in the same season $(2004 / 2005)\left(r_{8}=0.83 ; P<0.01\right)$ (ii) when the site (Cambridge) and technique (SVP) were kept constant but the seasons and ramets differed (2004/2005 and $2005 / 2006)\left(r_{7}=0.98 ; P<0.001\right)$, (iii) when the pollination technique (MSP) was kept constant but the sites (CAMBRIDGe and RIDGLEY) and seasons differed (2004/2005 and 2005/2006) $\left(\mathrm{r}_{6}=0.98 ; P<0.001\right)$, and (iv) when site (CAMBRIDGE and RIDGLEY), season (2004/2005 and 2005/2006) and pollination technique (OP and MSP) differed $\left(\mathrm{r}_{5}=0.99 ; P<0.001\right)$.

\section{Discussion}

Reproductive success was found to be highly variable under operational conditions across 12 seasons and 11 sites. Pollination technique was found to clearly affect the success of crossing, with the current single visit pollination (SVP) technique (HARBARD et al., 1999; WILLIAMS et al., 1999) resulting in a higher level of reproductive success than the original three visit technique (TVP) (ELDRIDGE et al., 1993; MonCUR, 1995). This was consistent with previous studies which have shown that fertilisation and seed set were successful, if not improved with the SVP technique (HARBARD et al., 1999; WILLIAMS et al., 1999). The only other significant factors detected in the operational crossing, were the random female and male effects, however the percentage of variation explained by them was low. Although the female race effect was bordering on significance there was no consistent trend regarding female/male contribution of parental race which could be detected from this data. In the operational data the male and female effects were confounded by numerous factors due to the sparse nature and spread of the data over sites and seasons and the general absence of replication of the pollen collections and ramets used. These factors include differing graft ages, flowering times (GORE and PoTTs, 1995), operators, environmental conditions and silvicultural treatments such as pruning and paclobutrazol application. For example, application of the flowering promoter, paclobutrazol, has been shown to negatively affect capsule set (CAllister and Collins, 2007). Due to the absence of replication at a ramet level in most cases and of a significant race effect, and the potential confounded factors it was not possible to determine whether the observed variation between males and female had a genetic basis.

When a more targeted study was undertaken at a single site, with a uniform pollination technique (SVP) on similarly aged and treated grafts with much better replication in terms of crosses performed, the female effect reported was very large and significant, the male effect was small, and there was a significant female race effect. This result, whereby females of multiple races were effectively randomly distributed throughout the orchard is evidence for a genetic basis to the variation in female reproductive success. Previous research (SUITOR et al., 2008a) has reported numerous flower physical associations with reproductive success and it appeared that larger floral features resulted in higher reproductive success. Fruit size has been shown to vary considerably in eucalypts (GILL et al., 1992). Morphological studies (JORDAN et al., 1993; KIRKPATRICK, 1975) have shown that there are significant differences between populations of $E$. globulus both between and within races for capsule size characteristics such as capsule diameter and height, and a genetic basis to the variation has been demonstrated (McGowen, 2007).

The lack of a significant interaction between parents in the diallel from different races is evidence that postmating reproductive barriers between races are absent, at least with the stigma removed and up to the stage of seed set. Reproductive barriers do exist between races of $E$. globulus, as studies in a common environment field trials indicated large genetic based differences in flowering time (APIOLAZA et al., 2001; PоTTS and GoRE, 1995). Flowering therefore constitutes a significant pre-mating barrier to natural crossing. Races in this study also differ significantly in flower size (MCGowen, 2007), with those of Strzelecki Ranges having smaller flowers than Furneaux and Otways races. Differences in flower size have been shown to be a significant post-mating barrier to hybridisation in eucalypts (GORE et al., 1990).

Previous studies at a broader taxonomic level in Eucalyptus have also indicated a reduction in seed set occurs with increasing taxonomic difference between hybridising species, possibly through physiological incompatibility (ELLIS et al., 1991). In the present case, while the Strzelecki Ranges and Otways races belong to the same molecular lineage of E. globulus, the Furneaux Group race is more divergent and belongs to an Eastern Tasmanian molecular lineage (STEANE et al., 2006). However, the absence of any male $\mathrm{x}$ female race interaction in the diallel crossing scheme, indicating no significant difference in reproductive success between inter- and intra-race crosses, would argue against the existence of either physical or physiological post mating reproductive barriers to seed set in crosses amongst the races studied.

The male effect was found to be significant at both the operational scale and within the diallel crossing scheme. Non-optimal storage conditions reduced viability and differences in storage times resulted in some pollen in 
the diallel crossing scheme having low viability. Subsequently a positive correlation between reproductive success and pollen viability was identified, when the full data set including the use of the fresh and stored pollen was used. The use of pollen that had been collected and stored for a year, resulted in a markedly lower level of seeds per flower than pollinations made with pollen collected that season. Therefore the significant male effect in the diallel crossing scheme and most likely in the operation scale data, when conditions were less controlled, was likely to be a consequence of pollen management and the time of pollen collection. The absence of a male race effect in reproductive success in either operational crossing or the diallel would argue against a genetic basis to the variation in male fecundity.

The genetic basis to female reproductive success alluded to in the operational crossing (with the female race effect on the borderline of significance) and detected at the race level in the diallel crossing trials was confirmed in a subsequent correlation of female genotypes that were common to both datasets. Subsequent studies of repeated crosses of different ramets of the same genotypes at different sites and seasons also clearly indicate the stability of female effects, despite the expected variation due to the exogenous factors of site, pollination type (SUITor et al., 2008b) and season (LEAL and CoTTERILL, 1997). The fact that these female genotype effects were stable when different ramets were used provides good evidence for a genetic basis to the female variation in reproductive success.

Forest tree breeding has evolved to mostly focus on the importance of growth and wood quality (RAYMOND and APIOLAZA, 2004) and breeders rarely consider reproductive traits in breeding programs (HAINES and Woolaston, 1991; RAYmond and ApIolazA, 2004; SEDGLEY and GRIFFIN, 1989). According to RIDLEY (1996) the selective value of a trait is directly related to its genetic co-variation with reproductive output. Understanding of the genetic basis of variation in reproductive traits, particularly reproductive success, is important for predicting evolutionary responses to natural selection (FALCONER and MACKAY, 1996) as well as managing breeding and deployment populations. Genetic co-variation between reproductive output and a selection trait may have a negative impact on the timing of the onset of reproduction and hence generation time as well as the cost of seed production. For example, selection for fast growth may result in reduced reproductive output due to changes in resource allocation (BoNNIN et al., 1997; Chalupka and CECICH, 1997; SEDGley and GRIFFIn, 1989; Strauss et al., 1995). No significant adverse genetic correlations between sexual reproductive traits and pulpwood selection traits have as yet been reported within populations of $E$. globulus (CHAMBERS et al., 1997; McGowen, 2007). However at the race level the marked differences in reproductive output are evident for sexual reproduction under both open pollination (McGowen, 2007) and controlled pollination (present study) as well as for success of vegetative propagation (CAÑAS et al., 2004). Such genetic based differences will no doubt add significantly to the costs of propagation of germplasm from specific races in E. globulus breeding and the prediction of breeding or deployment values for propagation traits, such as female reproductive success, is suggested as a means of better modelling the economic worth of germplasm and guiding deployment decisions. Consequently reproductive traits could be summarised as a selection trait (cost of seed) and incorporated into index calculations.

\section{Acknowledgements}

This research was funded by SeedEnergy Pty Ltd and an Australian Postgraduate Award to SHAun Suitor. We thank Paul Tilyard, Kelsey Joyce and Gunns Ltd for their assistance.

\section{References}

ApiolazA, L. A, B. M. PotTs and P. L. Gore (2001): Genetic control of peak flowering time of Eucalyptus globulus. In 'Developing the Eucalypt of the Future'. Valdivia, Chile. (INFOR)

Boland, D. J., M. I. H. Brooker, J. W. Turnbull and D. A. KLeinig (1980): 'Eucalyptus Seed.' (Hogbin Poole Pty. Ltd.: Sydney)

Bonnin, I., J. M. Prosperi and I. OlivieRI (1997): Comparison of quantitative genetic parameters between two natural populations of a selfing plant species, Medicago truncatula gaertn. Theoretical \& Applied Genetics 94, 641-651.

Brooker, M. I. H. (2000): A new classification of the genus Eucalyptus L'Her. (Myrtaceae). Australian Systematic Botany 13, 79-148.

CAllister, A. N. and R. J. Collins (2007): Genetic selection reduces the cost of Eucalyptus globulus seed produced by mass supplementary pollination. In 'IUFRO Working Group 2.08.03: Eucalypts and Diversity Balancing Productivity and Sustainability'. Durban, South Africa p. 54. (CD Rom)

Cañas, I., F. Soria, G. López, R. Astorga and G. Toval (2004): Genetic parameters for rooting trait in Eucalyptus globulus (Labill.). In: 'Eucalyptus in a changing world'. Aveiro, Portugal. (Eds N. M. G. Borralho, J. S. Pereira, C. Marques, J. Coutinho, M. Madeira and M. TomÉ) pp. 159-160. (RAIZ, Instituto Investigação de Floresta e Papel)

Chalupka, W. and R. A. Cecich (1997): Control of the first flowering in forest trees. Scandinavian Journal of Forest Research 12, 102-111.

Chambers, P. G. S., B. M. Potts and P. Tilyard (1997): The genetic control of flowering precocity in Eucalyptus globulus ssp. globulus. Silvae Genetica 46, 207-214.

Cotterill, P., S. MACRAe and A. Brolin (1999): Growing eucalypt for high-quality papermaking fibres. Appita Journal 52, 79-83.

DRAKE, D. W. (1981): Reproductive success of two Eucalyptus hybrid populations. I. Generalized seed output model and comparison of fruit parameters. Australian Journal of Botany 29.

Dutkowski, G. W. (2004): GSIM - a tree breeding and deployment simulator. In: 'Eucalyptus in a Changing World'. Aveiro, Portugal. (Eds N. M. G. BorralHo, J. S. Pereira, C. Marques, J. Coutinho, M. Madeira and M. TomÉ) p. 189. (RAIZ, Instituto Investigação de Floresta e Papel). 
Dutkowski, G. W. and B. M. Pоттs (1999): Geographic patterns of genetic variation in Eucalyptus globulus ssp. globulus and a revised racial classification. Australian Journal of Botany 47, 237-263.

ELDRIDGE, K., J. DAVIDSON, C. HARWOOD and G. VAN WYK (1993): 'Eucalypt Domestication and Breeding.' (Clarendon Press, Oxford)

Ellis, M. F., M. SEDGLey and J. A. GARDNER (1991): Interspecific pollen pistil interaction in Eucalyptus (Myrtaceae) - the effect of taxonomic distance. Annals of Botany 68, 185-194.

FALCONER, D. S. and T. F. C. MACKAY (1996): 'Introduction to Quantitative Genetics.' (Longman Scientific and Technical: New York)

Foster, S. A., G. E. McKinnon, D. A. Steane, B. M. Potts and R. E. VAillancourt (2007): Parallel evolution of dwarf ecotypes in the forest tree Eucalyptus globulus. New Phytologist 175, 370-380.

GiLl, A. M., M. I. H. Brooker and P. H. R. Moore (1992): Seed weights and numbers as a function of fruit size and subgenus in some Eucalyptus species from southwestern Australia. Australian Journal of Botany 40, 103-111.

Gore, P. L. and B. M. РотTS (1995): The genetic control of flowering time in Eucalyptus globulus, E. nitens and their $\mathrm{F}_{1}$ hybrids. In: 'Eucalypt Plantations: Improving Fibre Yield and Quality'. Hobart, Tasmania. (Eds B. M. Potts, N. M. G. Borralho, J. B. Reid, R. N. Cromer, W. N. TibBits and C. A. Raymond) pp. 241-242. (CRC for Temperate Hardwood Forestry)

Gore, P. L., B. M. Potts, P. W. Volker and J. Megalos (1990): Unilateral cross-incompatibility in Eucalyptus: the case of hybridisation between $E$. globulus and E. nitens. Australian Journal of Botany 38, 383-94.

GRIFFIN, A. R. (2001): Deployment decision, capturing the benefits of tree improvement with clones and seedlings. In: 'IUFRO international symposium: Developing the Eucalypt of the Future'. Valdivia, Chile p. 16. (Instituto Forestal: Valdivia, Chile)

HAines, R. J. and R. R. Woolaston (1991): The influence of reproductive traits on the capture of genetic gain. Canadian Journal of Forest Research 21, 272-275.

HARBARD, J. L., A. R. GRIFFIN and J. EspeJo (1999): Mass controlled pollination of Eucalyptus globulus: a practical reality. Canadian Journal of Forest Research 29, 1457-1463.

HaRdNeR, C. M. and B. M. PotTs (1995): Inbreeding depression and changes in variation after selfing Eucalyptus globulus subsp. globulus. Silvae Genetica 44, $46-54$.

Hardner, C. M., R. E. Vaillancourt and B. M. Potts (1996): Stand density influences outcrossing rate and growth of open-pollinated families of Eucalyptus globulus. Silvae Genetica 45, 226-228.

Hodge, G. R., P. W. Volker, B. M. Potts and J. V. Owen (1996): A comparison of genetic information from openpollinated and control-pollinated progeny tests in two eucalypt species. Theoretical and Applied Genetics 92, $53-63$.

Jones, T. H., D. A. Steane, R. C. Jones, D. Pilbeam, R. E. VAillancourt and B. M. PotTs (2006): Effects of domestication on genetic diversity in Eucalyptus globulus. Forest Ecology and Management 234, 78-84.

Jordan, G. J., B. M. PotTs, J. B. KirKPatrick and C. GarDINER (1993): Variation in the Eucalyptus globulus complex revisited. Australian Journal of Botany 41, 763-785.
KIRKPATRICK, J. B. (1975): 'Geographical Variation in Eucalyptus globulus.' (Australian Government Publishing Service: Canberra).

Leal, A. M. and P. P. CotTerill (1997): Mass controlled pollination of Eucalyptus globulus. In: 'IUFRO Conference on Silviculture and Improvement of Eucalypts'. Brazil. (Eds A. R. Higa, E. Schaitza and S. GaiAD) pp. 256-258. (EMBRAPA).

McGowen, M. (2007): Genetic control of reproductive traits in Eucalyptus globulus. $\mathrm{PhD}$ thesis, University of Tasmania.

McGowen, M. H., B. M. Potts, R. E. Vaillancourt, P. Gore, D. R. Williams and D. J. Pilbeam (2004a): The genetic control of sexual reproduction in Eucalyptus globulus. In: 'Eucalyptus in a Changing World'. Aveiro, Portugal. (Eds N. M. G. BorralHo, J. S. PEREira, C. Marques, J. Coutinho, M. Madeira and M. Tomé) pp. 104-108. (RAIZ, Instituto Investigação de Floresta e Papel).

McGowen, M. H., D. R. Williams, B. M. Potts and R. E. VAILLANCOURT (2004b): Stability of outcrossing rates in Eucalyptus globulus seedlots. Silvae Genetica 53, $42-44$.

Moncur, M. W. (1995): 'Techniques for Pollinating Eucalypts.' Australian Centre for International Agricultural Research, 30, Canberra.

Patterson, B., P. Gore, B. M. Potts and R. E. VaillanCOURT (2004a): Advances in pollination techniques for large-scale seed production in Eucalyptus globulus. Australian Journal of Botany 52, 781-788.

Patterson, B., R. E. Vaillancourt, D. J. Pilbeam and B. M. PotTs (2004b): Factors affecting variation in outcrossing rate in Eucalyptus globulus. Australian Journal of Botany 52, 773-780.

Patterson, B., R. E. Vaillancourt and B. M. Potts (2001): Eucalypt seed collectors: beware of sampling seedlots from low in the canopy! Australian Forestry 64, 139-142.

Pilbeam, D. J. and G. W. Dutkowski (2004): Simulation to determine optimal wood quality sampling strategies. In: 'Eucalyptus in a Changing World'. Aveiro, Portugal. (Eds N. M. G. Borralho, J. S. Pereira, C. Marques, J. Coutinho, M. Madeira and M. Tomé) pp. 211-212. (RAIZ, Instituto Investigação de Floresta e Papel)

PotTs, B. M. (1986): The population dynamics and regeneration of a hybrid zone between Eucalyptus risdonii and E. amygdalina. Australian Journal of Botany 34, 305-329.

PotTs, B. M. (2004): Genetic improvement of eucalypts. In: 'Encyclopedia of Forest Science'. (Eds J. Evans, J. Burley and J. YoungQuist) pp. 1480-1490. (Elsevier Science: Oxford).

PotTs, B. M. and P. Gore (1995): 'Reproductive biology and controlled pollination of Eucalyptus - a review.' School of Plant Science, University of Tasmania, Hobart.

Potts, B. M. and J. B. Marsden-Smedley (1989): In vitro germination of Eucalyptus pollen: response to variation in boric acid and sucrose. Australian Journal of Botany 37, 429-441.

Potts, B. M., M. H. McGowen, D. R. Williams, S. Suitor, P. L. Gore and R. E. VAILlancourt (2007): Advances in reproductive biology and seed production systems of Eucalyptus: The case of Eucalyptus globulus. In: 'IUFRO Working Group 2.08.03: Eucalypts and Diversity Balancing Productivity and Sustainability'. Durban, South Africa p. 15. (CD Rom). 
Potts, B. M., M. H. McGowen, D. R. Williams, S. Suitor, T. H. Jones, P. L. Gore and R. E. Vaillancourt (2008): Advances in reproductive biology and seed production systems of Eucalyptus: The case of Eucalyptus globulus. Southern Forests 70, 145-154.

PotTs, B. M. and J. B. ReID (1983): Hybridisation between Eucalyptus obliqua L'Herit. and E. pulchella Desf. Australian Journal of Botany 31, 211-229.

RAYMOND, C. A. and L. A. APIOLAZA (2004): Incorporating wood quality and deployment traits in Eucalyptus globulus and Eucalyptus nitens. In: 'Plantation forest biotechnology for the $21^{\text {st }}$ century'. (Research Signpost: Trivandrum India).

RIDley, M. (1996): 'Evolution.' (Blackwell Science Inc.: Cambridge, Massachusetts).

SAS Institute Inc (2003): SAS 9.1 for Windows. In. (SAS Institute: Cary, NC, USA).

SAsse, J., M. LAVERY and M. HAmilton (2003a): Seed crop management of Eucalyptus globulus-development of seed crops and their readiness to harvest in individual trees. In: 'ACIAR international conference'. Zhanjiang, Guandong, People's Republic of China pp. 126-132.

SAsse, J., M. LAVERY and M. Hamilton (2003b): Spatial variation in capsule and seed crops within crowns of Eucalyptus globulus in a seed orchard. In: 'Eucalypts in Asia'. Zhanjiang, Guangdong, People's Republic of China. (Ed. J. W. TURnBulL) pp. 133-139. (Australian Centre for International Agricultural Research).

SEDGley, M. and A. R. GRIFfin (1989): 'Sexual Reproduction of Tree Crops.' (Academic Press Limited: London).

Steane, D. A., N. Conod, R. C. Jones, R. E. Vaillancourt and B. M. PotTs (2006): A comparative analysis of population structure of a forest tree, Eucalyptus globulus (Myrtaceae), using microsatellite markers and quantitative traits. Tree Genetics and Genomes 2, 30-38.
Strauss, S. H., W. H. Rottmann, A. M. Brunner and L. A. SHEPPARD (1995): Genetic engineering of reproductive sterility in forest trees. Molecular Breeding. 1, 5-26.

Suitor, S., B. M. PotTs, P. B. Brown, A. J. Gracie and P. Gore (2007): Factors affecting capsule set in Eucalyptus globulus seed orchards. In: 'IUFRO Working Group 2.08.03: Eucalypts and Diversity Balancing Productivity and Sustainability'. Durban, South Africa p. 8. (CD Rom).

Suitor, S., B. M. Potts, P. B. Brown, A. J. Gracie and P. GoRE (2008a): The relationship of Eucalyptus globulus female reproductive success to endogenous properties of the flower. Sexual Plant Reproduction. In press.

Suitor, S., B. M. Potts, P. B. Brown, A. J. Gracie and P. L. Gore (2008b): Post pollination capsule development in Eucalyptus globulus seed orchards. Australian Journal of Botany $\mathbf{5 6}, 51-58$.

Tibits, W. N., D. B. Boomsma and S. Jarvis (1997): Distribution, biology, genetics, and improvement programs for Eucalyptus globulus and E. nitens around the world. In: '24 th $^{\text {th }}$ Southern Forest Tree Improvement Conference'. Orlando, Florida. (Eds T. White, D. Huber and G. Powell) pp. 1-15. (Southern Tree Improvement Committee).

Venter H. and A. SilvLal (2007): Fluorescence microscopy study of the effect of TVP, OSP and AIP cross pollination on successful pollen germination on the stigma. In: 'IUFRO Working group 2.08.03 - Eucalypts and diversity: balancing productivity and sustainability'. Durban, South Africa p. 12. (CR ROM)

VOLKER, P. W. (2002): Quantitative genetics of Eucalyptus globulus, E. nitens and their $\mathrm{F}_{1}$ hybrid. Ph.D. thesis, University of Tasmania.

Williams, D. R., B. M. Potts and P. G. Black (1999): Testing single visit pollination procedures for Eucalyptus globulus and E. nitens. Australian Forestry 62, 346-352. 